\title{
Pengaruh Persepsi Wajib Pajak atas Penerapan E-Filing dan Persepsi Wajib Pajak atas Kualitas Sistem E-Filing Terhadap Kepatuhan Pajak
}

\section{THE EFFECT OF TAXPAYER'S PERCEPTION ON THE APPLICATION OF E- FILING AND THE PERCEPTION OF TAXPAYER'S QUALITY OF THE SYSTEM E-FILING ON TAX COMPLIANCE}

\author{
Anisa Widya Larasati ${ }^{1}$, Diyah Probowulan', Achmad Syahfrudin ${ }^{3}$ \\ Universitas Muhammadiyah Jember ${ }^{1,2,3}$ \\ anisawidya148@gmail.com ${ }^{1}$
}

\begin{abstract}
E-Filing is a system for the achievement of annual report letters (SPT) which is done online and in real time to the Directorate General of Taxes through the official website of the Directorate General of Taxes. This study aims to examine the effect of perceptions of taxpayers on the application of E-filing and perceptions of taxpayers on the quality of e-filing systems for tax compliance in the Jember Pratama KPP case study. This research uses quantitative methods. The number of samples used is 100 taxpayers who use the eFiling system. The data used in this study are primary data in the form of questionnaires distributed to taxpayer respondents. The results in this study indicate that taxpayer perceptions affect tax compliance and the quality of the e-Filing system has no effect on tax compliance.
\end{abstract}

Keywords: E-Filling, Perception, E-Filing System Quality, Complaints

\section{ASBTRAK}

E-Filing merupakan suatu sistem untuk penyamapaian surat laporan Tahuanan (SPT) yang dilakukan secara online dan real time kepada Direktorat Jenderal Pajak melalui website resmi Direktorat Jenderal Pajak. Penelitian ini bertujuan untuk menguji pengaruh persepsi wajib pajak terhadap penerapan E-filing dan persepsi wajib pajak terhadap kualitas sistem e-filing terhadap kepatuhan pajak dalam studi kasus KPP Jember Pratama. Penelitian ini menggunakan metode kuantitatif. Jumlah sampel yang digunakan adalah 100 wajib pajak yang menggunakan sistem e-Filing. Data yang digunakan dalam penelitian ini adalah data primer berupa kuesioner yang dibagikan kepada responden wajib pajak. Hasil dalam penelitian ini menunjukkan bahwa persepsi wajib pajak mempengaruhi kepatuhan pajak dan kualitas sistem e-Filing tidak berpengaruh pada kepatuhan pajak.

Kata Kunci: E-Filling, Persepsi, Kualitas Sistem E-Filing, Keluhan

\section{PENDAHULUAN}

Seiring perkembangan zaman perekonomian negara di Indonesia akan terus diikuti dengan kebijakan-kebijakan di sektor perpajakan. Dilihat pada sisi pekerjaannya, manusia membutuhkan sebuah arus informasi berupa data atau informasi secara cepat sehingga membutuhkan akses internet untuk menunjang pekerjaan mereka (Surjati, 2007). Berdasarkan pajak nomor 16 Tahun 2009 “ pajak adalah kontribusi 
wajib pajak kepada Negara yang terutang oleh orang peribadi atau badan yang bersifat memaksa berdasarkan Undang-Undang dengan tidak mendapat imbalan secara langsung dan digunakan untuk keperluan Negara sebesar besarnya kemakmuran rakyat". Bersadarkan dari hasil persentase APBN 2012 -2017 telah menunjukan bahwa penerimaan pajak merupakan penerimaan yang paling besar dibandingkan penerimaan Negara yang lainnya. Menurut Badan Pusat Statistik jumlah penerimaan negara pada Tahun 2010 -2014 meningkat sebesar 14\% yaitu pada Tahun 2010 sebesar 723.307 miliyar rupiah Tahun 2011 sebesar 873.874 miliyar rupiah Tahun 2012 sebesar 980.518 miliyar rupiah, Tahun 2013 sebesar 1.148.365 miliyar rupiah dan Tahun 2014 sebesar 1.310.219 miliyar rupiah.

Dengan itu Direktorat Jenderal Pajak berupaya untuk lebih meningkatkan kembali penerimaan pajak sehingga dapat mencapai target yang telah ditetapkan dan fakta yang terberat bahwa faktanya kepatuhan wajib pajak di Negara Indonesia masihlah rendah sehingga untuk meninggkatkan kepatuhan wajib pajak , Derektorat Jenderal Pajak berupaya untuk mengoptimalkan pelayanan sehingga dapat diharapkan kesadaran wajib pajak untuk tertib dalam melporkan pajak. Salah satu reformasi yang dilakukan Direktorat Jenderal Pajak yaitu memanfaatkan sistem teknologi informasi dan komunikasi yaitu dengan menerapkan sistem e-Filing.

Penelitian ini berfokus pada reformasi administrasi perpajakan manual ke perpajakan elektronik yaitu sistem e-Filing. E-Filing merupakan suatu sistem untuk penyamapaian surat laporan Tahuanan (SPT) yang dilakukan secara online dan real time kepada
Direktorat Jenderal Pajak melalui website resmi Direktorat Jenderal Pajak.

Penelitian ini berkaitan dengan persepsi wajib pajak atas penerapan eFiling dan kualitas sistem E-Filing yaitu antara lain Rakayana (2016) Menyimpulkan bahwa persepsi kebermanfaatan, kemudahaan, kepuasan berpengaruh signifikan terhadap kepatuahan pelaporan SPT Tahunan. Solikah dan Kusumaningtiyas (2017) menyimpulkan bahwa kualitas sistem eFiling berpengaruh signifikan terhadap kepatuhan SPT Tahunan.

Penelitian ini mengembangkan dari penelitian tentang faktor-faktor yang mempengaruhi kepatuhan pajak. Sehingga saya sebagai peneliti ingin menelti secara khusus membahas tentang persepsi wajib pajak atas penerpan e-Filing dan persepsi wajib pajak atas kualitas sistem e-Filing karena belum banyak yang secara khusus meneliti variabel-variabel tersebut.

Tabel 1 Rasio Kepatuhan SPT

\begin{tabular}{cccc}
\hline $\begin{array}{c}\text { Tahu } \\
\mathrm{n}\end{array}$ & $\begin{array}{c}\text { Total } \\
\text { SPT } \\
\left(\begin{array}{c}\text { Peroran } \\
\text { g) }\end{array}\right.\end{array}$ & $\begin{array}{c}\text { WP } \\
\text { Wajib } \\
\text { Pajak } \\
\text { (Peroran } \\
\text { g) }\end{array}$ & $\begin{array}{c}\text { Kepatuha } \\
\text { n } \\
\text { Pelapora } \\
\text { n SPT }\end{array}$ \\
\hline 2015 & 69.789 & 91.720 & $76,09 \%$ \\
\hline 2016 & 71.143 & 109.660 & $64,88 \%$ \\
\hline 2017 & 71.433 & 90.800 & $78,67 \%$ \\
\hline 2018 & 70.932 & 80.061 & $88,60 \%$ \\
\hline \multicolumn{4}{c}{ Pada rasio kepatuhan SPT tahuan }
\end{tabular}

diatas telah menunjukan bahwa pada KPP partama pada Tahun 2015- 2018 mengalami ketidak stabilan dalam kepatuan pelaporan SPT Taahunan. Sehingga saya sebagai peneliti ingin meneliti apakah Variabel-Variabel dalam penelitian ini dapat menjadi sebab dari wajib pajak KPP Pratama Jember tidak melakukan kewajib pajaknya dengan baik.

Berdasarkan latar belakang masalah yang telah dipaparkan maka penuliskan membuat penelitian berjudul" Pengaruh Persepsi Wajib 
Pajak atas Penerapan E-Filing dan persepsi wajib pajak atas Kualitas Sistem E-Filing terhadap Kepatuhan Pajak. Jogiyanto (2008) model penerimaan teknologi TAM adalah model yang menjelaskan tentang penerimaan suatu sistem teknologi informasi yang akan digunakan oleh pemakai (user). Model penerimaan teknologi atau technology acceptance model (TAM) dikembangkan oleh Devis (1989) berdasarkan model TRA (Teory of Reasoned Action). TRA adalah suatu well-researched intention sebagai model khusus yang telah terbukti berhasil untuk memprediksi dan menjelaskan tentang perilaku seseorang dalam memanfaatkan dengan beraneka ragam bidang. TAM berpendapat bahwa keputusan penerimaan indivdu terhadap sistem teknologi infomasi ditentukan oleh dua kontruks yaitu persepsi manfaat dan persepsi kemudahan.

Peter, Delone \& Me Clean (2008) telah menghasilkan sejumlah model untuk menjelaskan apa yang membuat beberapa kesuksesan Sistem Informasi. Davis's (1989) Technology Acceptance Model (TAM) menggunakan Theory of Reasoned Action and Theory of Planned Behavior (Fishbein \& Ajzen, 1975) untuk menjelaskan mengapa beberapa Sistem Informasi lebih mudah diterima oleh pengguna dari pada yang lain. Penerimaan, bagaimanapun tidak setara dengan kesuksesan meskipun penerimaan suatu sistem informasi merupakan prasyarat penting bagi kesuksesan (Petter et al., 2008).

Pajak Pasal 1 Ayat 1 UU No.28 Tahun 2007 tentang perubahan ketiga atas UU Nomor 6 Tahun 6 Tahun 1983 tentang Ketentuan Umum dan Tata Cara Perpajakan, "Pajak adalah kontribusi wajib kepada negara yang terutang oleh orang pribadi atau badan yang bersifat memaksa berdasarkan undang-undang, dengan tidak mendapatkan imbalan secara langsung dan digunakan untuk keperluan negara bagi sebesar-besarnya kemakmuran rakyat".

Dalam Pasal 1 ayat (2) UU Nomor 6 Tahun 1983 tentang Ketentuan Umum dan Tata Cara Perpajakan sebagaimana telah diubah terakhir dengan UU Nomor 16 Tahun 2009 (UU KUP) mendefiniksikan " Wajib Pajak adalah orang atau badan, meliputi pembayaran pajak, pemotongan pajak, pemungutan pajak, yang mempunyai hak dan kewajiban perpajakan sesuai dengan ketentuan peraturan undang-undang perpajakan".

Pandiangan (2008) e-Filing adalah suatu cara penyampaian SPT yang dilakukan melalui sistem online dan real time. Online berarti bahwa Wajib Pajak dapat melaporkan pajak melalui internet dimana saja dan kapan saja, sedangkan kata real time berarti bahwa konfirmasi dari Direktorat Jenderal Pajak (DJP) dapat diperoleh saat itu juga apabila data-data Surat Pemberitahuan (SPT) yang diisi dengan lengkap dan benar telah sampai dikirim secara elektronik.

Desmita (2009) “perception dalam pengertian sempit adalah penglihatan, yaitu bagaimana seseorang melihat sesuatu sedangkan dalam arti luas yaitu pandangan bagaimana seseorang memandang atau mengartikan sesuatu. Erdwad dkk. (2017), persepsi Wajib Pajak atas penerapan e-Filing telah didefinisikan sebagai salah satu faktor utama yang mempengaruhi adopsi inovasi atau teknologi baru. Menurut penelitian Laihad (2013) terdapat indikator persepsi yaitu: 1) persepsi manfaat, 2) persepsi Kemudahan, 3) persepsi kepuasan

Chen (2010), kualitas sistem merupakan merupakan ukuran dari sistem pengelolahan sistem. Sehingga dapat dinyatakan bahwa kualitas sistem e-Filing adalah ukuran dari sistem pengelohan informasi pada penyampaian 
SPT elektronik secara on-line yang real time melalui saluran tertentu yang ditetapkan oleh Direktorat Jenderal Pajak. Persepsi kualitas sistem e-Filing merupakan pandangan wajib pajak mengenai suatu sistem $e$-Filing, sebagai sistem untuk melaporkan SPT tahunan dengan elektronik (sistem e-Filing). Solikah dan Kusumaningtyas (2017) kualitas sitem e-Filing tersebut tergantung lima faktor yaitu: 1) akurasi, isi data basis, 2) kemudahan pengguna, 3) kemudahan di Pelajari, 4) realisasi Kebutuhan Pemakai

Berdasarkan Keputusan Menteri Keuangan No. 544/KMK.04/2000, yaitu: "Kepatuhan perpajakan adalah tindakan Wajib Pajak dalam pemenuhan kewajiban perpajakannya sesuai dengan ketentuan peraturan perundangundangan dan peraturan pelaksanaan perpajakan yang berlaku dalam suatu negara".

\section{METODE PENELITIAN}

Penelitian ini menggunakan satu variabel dependen dan dua variabel dependen yaitu variabel dependen adalah kepatuhan pajak dan variabel independen adalah persepsi wajib pajak atas penerapan e-Filing dan persepsi wajib pajak atas kualitas sistem e-Filing. Penelitian ini bertujian untuk mengetahui pengaruh persepsi wajib pajak atas penerapan e-Filing dan persepsi wajib pajak atas kualitas sistem e-Filing terhadap kepatuhan wajib pajak. Penelitian ini menggunakan jenis data kuantitatif dan sumber data yaitu data perimer dari survey secara langsung dengan menyebarkan kuesioner. Populasi dalam penelitian ini yaitu wajib pajak yang terdaftar di KPP Pratama Jember yang telah menggunakan sistem e-Filing pertanggal 31 Maret 2018. Jumlah sampel yang di gunakan yaitu 100 wajib pajak yang telah menggunakan sistem e-Filing. Teknik sampling yaitu accidental sampling . metote statistik yaitu menggunakan analisis regresi berganda dengan rumus sebagai berikut:

$$
\mathrm{Y}=a+\beta_{1} X_{1}+\beta_{2} X_{2}+e
$$

$$
\begin{aligned}
& \text { Keterangan: } \\
& \mathrm{Y}=\text { Kepatuhan pajak } \\
& \mathrm{a}=\text { Bilangan konstanta } \\
& \beta=\text { Koefisen regresi } \\
& X_{1}=\text { Persepsi Wajib Pajak atas } \\
& \text { penerapan } e \text {-Filing } \\
& X_{2}=\text { Persepsi Wajib Pajak atas } \\
& \text { Kualitas sistem } e \text {-Filing } \\
& \mathrm{E}=\text { Error }
\end{aligned}
$$

\section{HASIL DAN PEMBAHASAN \\ Deskripsi Penelitian}

Tabel 2 Deskripsi Penelitian

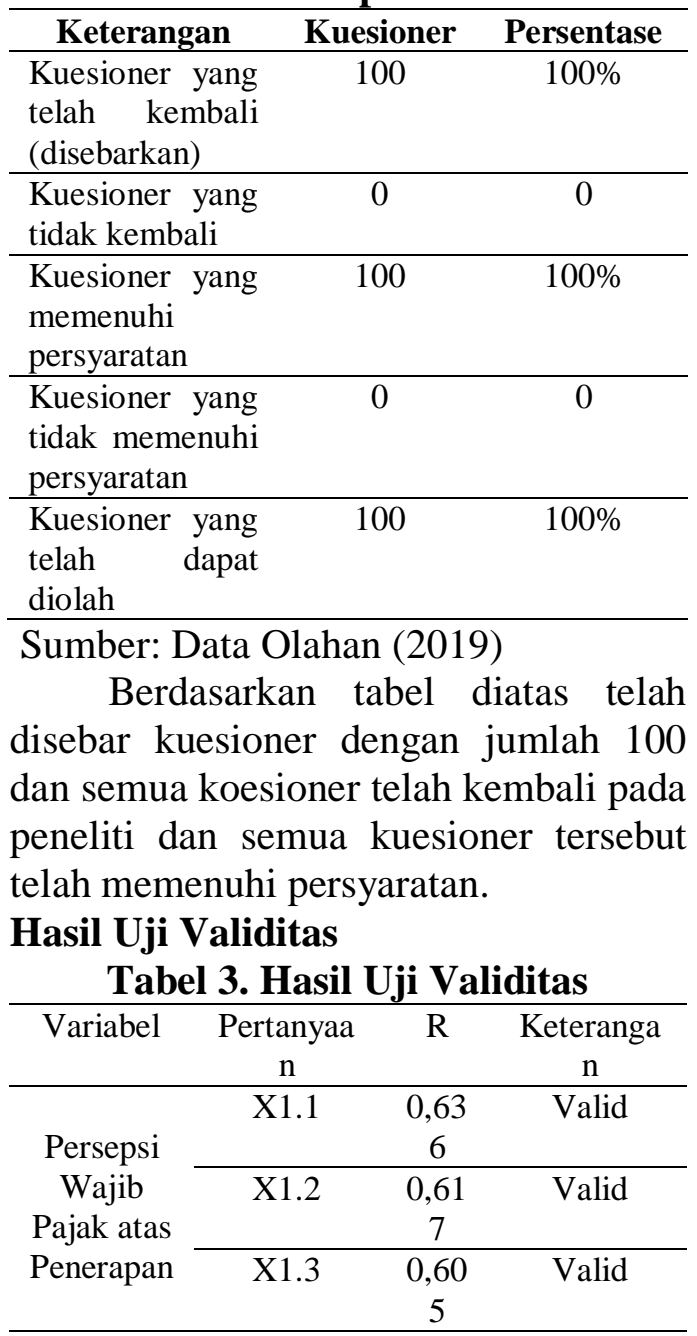




\begin{tabular}{|c|c|c|c|}
\hline \multirow[t]{2}{*}{$\begin{array}{l}\text { E-Filing } \\
\text { (X1) }\end{array}$} & $\mathrm{X} 1.4$ & $\begin{array}{c}0,56 \\
4\end{array}$ & Valid \\
\hline & $\mathrm{X} 1.5$ & $\begin{array}{c}0,66 \\
2\end{array}$ & Valid \\
\hline \multirow{5}{*}{$\begin{array}{l}\text { Persepsi } \\
\text { Wajib } \\
\text { Pajak atas } \\
\text { Kualitas } \\
\text { Sistem E- } \\
\text { Filing }\end{array}$} & $\mathrm{X} 2.1$ & $\begin{array}{c}0,73 \\
4\end{array}$ & Valid \\
\hline & $\mathrm{X} 2.2$ & $\begin{array}{c}0,61 \\
3 \\
\end{array}$ & Valid \\
\hline & $\mathrm{X} 2.3$ & $\begin{array}{c}0,66 \\
4\end{array}$ & Valid \\
\hline & $\mathrm{X} 2.4$ & $\begin{array}{c}0,57 \\
8\end{array}$ & Valid \\
\hline & $\mathrm{X} 2.5$ & $\begin{array}{c}0,58 \\
0\end{array}$ & Valid \\
\hline \multirow{5}{*}{$\begin{array}{c}\text { Kepatuha } \\
\text { n Pajak } \\
\text { (Y) }\end{array}$} & Y1 & $\begin{array}{c}0,66 \\
1\end{array}$ & Valid \\
\hline & Y2 & $\begin{array}{c}0,59 \\
8\end{array}$ & Valid \\
\hline & Y3 & $\begin{array}{c}0,59 \\
1\end{array}$ & Valid \\
\hline & Y4 & $\begin{array}{c}0,53 \\
7\end{array}$ & Valid \\
\hline & Y5 & $\begin{array}{c}0,56 \\
0\end{array}$ & Valid \\
\hline
\end{tabular}

Sumber: Data Olahan (2019)

Bersadarkan tabel diatas telah menunjukan bahwa variabel persepsi wajib pajak atas penerapan e-Filing dan persepsi wajib pajak atas kualitas sistem e-Filing terhadap kepatuhan pajak telah dinyatakan valid karena seluruh nilai tersebut $>0.30$.

\section{Hasil Uji Realiabilitas}

Tabel 4 Hasil Uji Reliabilitas

\begin{tabular}{|c|c|c|}
\hline Variabel & $\begin{array}{c}\text { Cronbach's } \\
\text { Alpha }\end{array}$ & Keterangan \\
\hline Persepsi & 0,741 & Reliabel \\
Wajib & & \\
Pajak atas \\
Penerapan \\
E-Filing & & \\
\hline $\begin{array}{c}\text { Persepsi } \\
\text { Wajib }\end{array}$ & 0,751 & Reliabel \\
Pajak atas & & \\
Kualitas & & \\
Sistem E- & & \\
Filing & & \\
\hline Kepatuhan & 0,727 & Reliabel \\
Pajak & & \\
\hline
\end{tabular}

Sumber: Data Olahan (2019)

Bedasarkan tabel diatas telah menunjukan bahwa variabel persepsi wajib pajak atas penerapan e-Filing dan persepsi wajib pajak atas kualitas sistem
e-Filing terhadapa kepatuhan pajak memiliki Crobach's Alpha lebih besar dari 0,60

\section{Analisis Regresi linear berganda} Tabel 5 Uji Regresi Berganda

\begin{tabular}{|c|c|c|c|c|c|c|}
\hline & Model & $\begin{array}{l}\text { Unstan } \\
\text { d Coef }\end{array}$ & $\begin{array}{l}\text { ardize } \\
\text { cients }\end{array}$ & $\begin{array}{l}\text { Standardized } \\
\text { Coefficients }\end{array}$ & $\mathrm{T}$ & Sig. \\
\hline & & B & $\begin{array}{l}\text { Std. } \\
\text { Error }\end{array}$ & Beta & & \\
\hline & $\begin{array}{l}\text { (Constan } \\
\text { t) }\end{array}$ & 9.445 & 1.563 & & 6.044 & .000 \\
\hline 1 & $\begin{array}{l}\text { Persepsi } \\
\text { Wajib } \\
\text { Pajak atas } \\
\text { Penerapa } \\
\text { n E- } \\
\text { Filing }\end{array}$ & .338 & .100 & .356 & 3.363 & .001 \\
\hline & $\begin{array}{l}\text { Persepsi } \\
\text { Wajib } \\
\text { Pajak atas } \\
\text { Kualitas } \\
\text { Sistem E- } \\
\text { Filing }\end{array}$ & .098 & .091 & .114 & 1.075 & .285 \\
\hline
\end{tabular}

Sumber: Data Olahan (2019)

Dalam penelitian ini maka telah di dapat persamaan regresi linera sebagai berikut :

$$
\mathrm{Y}=a+\beta_{1} X_{1}+\beta_{2} X_{2}+e
$$

$$
\mathrm{Y}=9,445+0.388 X_{1}+0.098 X_{2}+\mathrm{e}
$$

\section{Hasil Uji Nomalitas}

\begin{tabular}{|c|c|c|}
\hline & & $\begin{array}{c}\text { Unstandardized } \\
\text { Residual }\end{array}$ \\
\hline $\mathrm{N}$ & & 100 \\
\hline \multirow{2}{*}{$\begin{array}{l}\text { Normal } \\
\text { Parameters }\end{array}$} & Mean & .0000000 \\
\hline & Std. Deviation & 1.49794325 \\
\hline \multirow{3}{*}{$\begin{array}{l}\text { Most Extreme } \\
\text { Differences }\end{array}$} & Absolute & .108 \\
\hline & Positive & .062 \\
\hline & Negative & -.108 \\
\hline \multicolumn{2}{|c|}{ Kolmogorov-Smirnov Z } & 1.078 \\
\hline \multicolumn{2}{|c|}{ Asymp. Sig. (2-tailed) } & .195 \\
\hline
\end{tabular}

Tabel 6 Hasil Uji Normalitas

Sumber: Data Olahan (2019)

Dalam penelitian ini maka telah menunjukan bahwa nilai KolmogorovSmirnov lebih bersar dari 0,05

\section{Uji hipotesis}

Tabel 7. hasil Uji Statistik t 


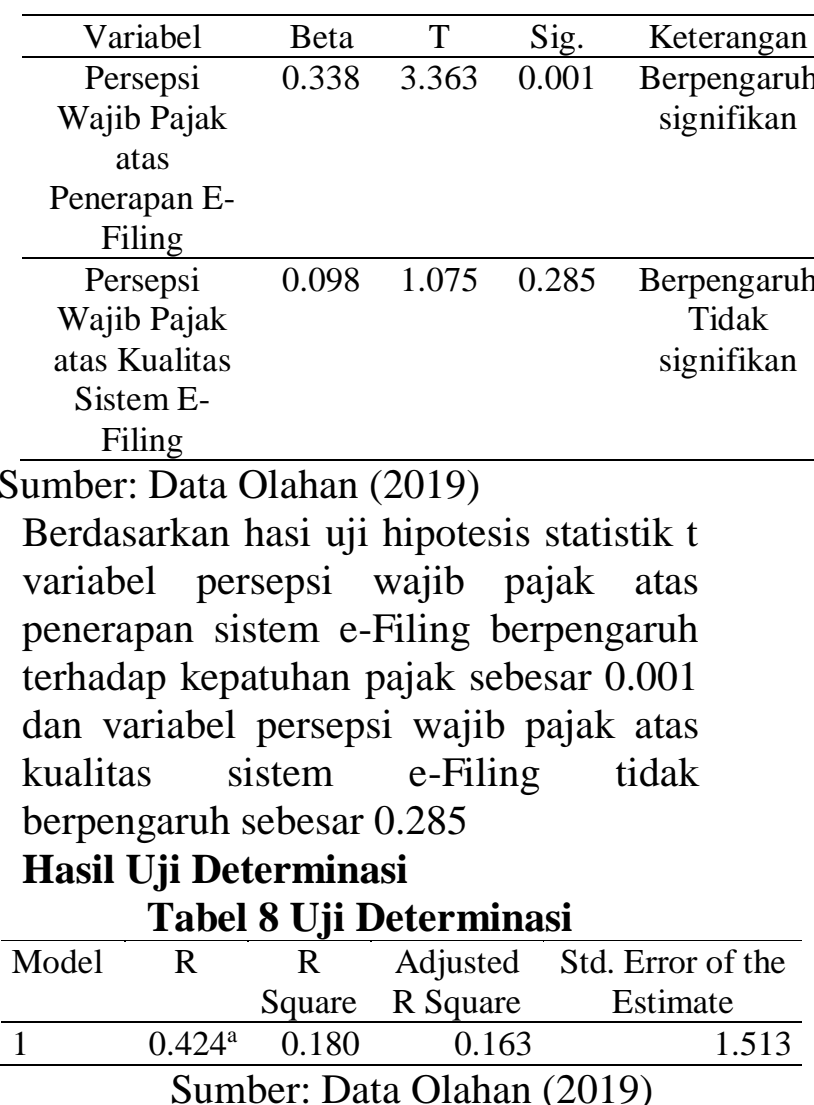

Bedasarkan tabel diatas telah menujukan bahwa $\mathrm{R}$ Square pada sebesar 0.180 maka berarti sebesar $18 \%$ variabel persepsi wajib pajak atas penerapan e-Filing dan Persepsi Wajib Pajak atas Kualitas Sistem E-Filing . Maka dapat dikatakan $82 \%$ kepatuhan wajib pajak di pengaruh oleh variabel lainnya.

\section{Hasil Persepsi Wajib Pajak Atas Penerapan Sistem E-Filing Terhadap Kepatuhan Pajak}

Hipotesis pertama menyatakan dugaan bahwa persepsi wajib pajak atas penerapan $e$-Filing berpengaruh terhadap kepatuhan wajib pajak. Hasil yang telah di dapatkan dari menggunakan metode analisis regresi liniear berganda, menunjukan bahwa persepsi wajib pajak atas penerapan $e$ Filing terhadap kepatuhan pajak dengan hasil t hitung 0,001. Nilai uji t hitung
Hasil penelitian ini menunjukan bahwa wajib pajak yang telah menggunakan sistem e-Filing merasa puas dan dengan menganggap bahwa sistem e-Filing dapat dingunakan dengan mudah dan lebih memberiakn manfaat bagi para wajib pajak. Manfaat yang didapatkan wajib pajak dalam penggunaan sistem $e$-Filing yaitu dapat melaporkan SPT Tahunan wajib pajak dengan lebih cepat dan tepat waktu dibandingkan manual. Dan kemudahan dalam menggunakan sistem e-Filing memicu wajib pajak untu secara sukarela melaporkan pajaknya, sehingga di harapkan dapat meningkatkan kepatuhan pajak.

Teori Technology Acceptance Model (TAM). TAM yaitu konsep yang digunakaan untuk memperkirakan sistem teknologi berpengaruh pada pemakai teknologi. Pada penelitian ini yang dimaksud sistem teknologi yaitu sistem e-Filing dan pemakai teknologi adalah Wajib Pajak. Sehingga apabila Wajib Pajak telah merasakan manfaat dan kemudahaan dalam pemakaian sistem e-Filing maka diharapkan sistem $e$-Filing dapat meningkatkan kepatuhan Wajib Pajak.

(2008) menjelaskan bahwa
pengembangan item-item konstruk ini difokuskan pada dua konstruk teoritis yaitu kegunaan persepsian (perceived usefulness) dan kemudahan penggunaan persepsian (perceived ease of use) yang secara teori merupakan penentu-penentu dasar dari penggunaan (use) dari sistem. Pemakai teknologi akan mempunyai niat menggunakan teknologi jika merasa sistem teknologi bermanfaat dan mudah digunakan maka sistem e-Filing tersebut dapat meningkatkan kepatuhan wajib pajak. 
Persepsi Wajib Pajak atas Kualitas Sistem E-Filing Terhadap Kepatuhan Pajak

Hipotesis kedua menyatakan bahwa kualitas sistem e-Filing berpengaruh terhadap ketauhan pajak. Hasil yang didapatkan dari analisis regresi linier berganda menunjukan bahwa Persepsi wajib pajak atas kualitas sistem e-Filing terhadap kepatuhan pajak dengan hasil t hitung 0,285 . Nilai uji t hitung lebih dari 0,05 sehingga $\mathrm{H} 2$ telah ditolak.

Hasil penelitian telah menunjukan bahwa sistem e-Filing dapat belum dapat membantu wajib pajak dalam melaporkan SPT Tahunan. Apabila wajib pajak telah menggunakan sistem $e$ Filing dengan tidak prima dalam melaporkan pajaknya dengan secara tidak mudah, tidak peraktis, lambat dan tidak akurat maka wajib pajak akan merasa menggunakan sistem e-Filing mendapati kesulitan dalam pelaporan SPT Tahunan.

Namun dalam beberapa hal bahwa sistem e-Filing pernah mengalami gangguan jaringan ketika para wajib pajak melakukan pelaporan SPT Tahuan. Oleh karena itu terjadi kegagalan dalam melaporkan SPT sehingga wajib pajak harus mengisi kembali data tersebut. Hal ini yang dapat menjadi masalah dalam sistem $e$-Filing apabila gangguan itu seringkali terjadi maka wajib pajak akan lebih sering melakukan keterlambatan dalam pelaporan SPT Tahunannya.

Kualitas sistem dalam penelitian ini dapat dihubungkan dengan teori kesuksesan sistem informasi DeLone \& Me Clean. Kualitas sistem didefinisikan sebagai karakteristik yang timbul karena suatu sistem. Karakteristik tersebut yaitu reliabel, kemudahaan penggunaan, kemudahaan dipelajari sedangkan use adalah karyawan dan Wajib Pajak yang menggunakan sistem $e$-Filing . Sehingga apabila Wajib Pajak mersa sistem $e$ Filing memiliki karaktersistik kualitas yang reliabel, kemudahaan penggunaan, kemudahan dipelajari maka sistem $e$ Filing tersebut diharapkan dapat meningkatkan kepatuhan kepada Wajib Pajak.

\section{PENUTUP}

Kesimpulan

Berdasarkan dari penelitian dan analisis yang telah terdapat pada pembahasan bab sebelumnya, maka di dapat kesimpulan sebagai berikut:

1. Persepsi wajib pajak atas penerapan e-Filing (X1) berpengaruh terhadap kepatuhan pajak (Y). Sehingga semakin baik persepsi wajib pajak atas penerpan $e$-Filing maka akan semakin meningkatakan kepatuhan pajak

2. Persepsi wajib pajak atas Kualitas sistem e-Filing (X2) tidak berpengaruh terhadap kepatuhan pajak (Y). Tidak signifikanya variabel kualitas sistem $e$-Filing disebabkan sistem e-Filing belum dapat membantu wajib pajak secara prima dalam melaporkan SPT Tahunan, sehingga tidak dapat mempengaruhi kepatuhan pajak.

\section{Saran}

Berdasarkan dari penelitian ini, saran yang dapat diajukan berdasarkan hasil dari penelitian ini sebagai berikut:

1. Wajib pajak setidaknya dalam melaporkan wajib pajak lebih teliti lagi dalam melaporkan SPT Tahunan dan pajaknya yang harus dibayarkan.

2. Bagi Kantor Pelayanan Pajak Pratama Jember sebaiknya lebih mensosialisasikan lagi dan mengencarkan kepada wajib pajak bahwa sistem e-Filing dapat memberikan banyak kemudahan, 
manfaat dan ketepatan waktu dalam melaporkan pajaknya.

3. Direktorat Jenderal Pajak diharapkan dapat lebih meningkatkan lagi kualitas dalam sistem $e$-Filing karena sering terjadi gangguan dalam melakukan pelaporan SPT Tahunan. Selain itu diharapkan Direktorat Jendral Pajak dapat mensosialisasikan mengenai cara pelaporan SPT Tahuan karena masih banyak wajib pajak yang belum mengerti peraturan yang berlaku tentang tempo waktu yang telah diberikan pada tanggal 31 maret bagi wajib pajak orang pribadi.

4. Bagi peneliti selanjutnya mengenai kepatuhan wajib pajak diharapkan dapat menambahkan dan mengembangkan variabel lainya dalam penelitian ini. Dikarenakan hasil dari koefisien determinasi menunjukan angka sebesar 18,0\% dan sisanya $82,0 \%$ dipengaruhi oleh variabel lain selain dari persepsi wajib pajak atas penerapan e-Filing dan kualitas sistem $e$-Filing.

\section{DAFTAR PUSTAKA}

Ajzen, I. and Fishbein, M. (1980). "Understanding Attitude and Predicting Social Behaviour". Prentice-Hall. Englewood Cliffs. NJ.

Chen, C.,W. 2010. Impact of Quality Antecedents on Taxpayer Satisfaction with Online Tax-filing Systems - An Empirical Study. Information \& Management, 47:308-315.

Davis, F. (1989). Perceived Usefulness, Perceived Ease of Use and User Acceptance of Information Technology. MIS Quarterly, 13(3), 319-340.

Desmita. (2009). Psikologi Perkembangan Peserta Didik. PT Remaja Rosdakarya. Bandung
Edward, K.,S \& Jagongo, A. (2017). Impact of Online Tax Filing on Tax Compliance Among Small and Medium Enterprises (MSE) in Kibwezi Sub-county in Kenya. International Journal of Current Research, 9(1): 45196-45206.

Jogiyanto, H. M. (2008). Sistem Informasi Keperilakuan. Penerbit : ANDI. Yogyakarta

Kementrian Keuangan. (2014). Peraturan Menteri Keuangan Nomor 206.2/PMK.01/2014 tentang Organisasi dan Tata Kerja Instansi Vertikal Direktorat Jenderal Pajak. Jakarta.

Kementrian Keuangan. (2014). Peraturan Menteri Keuangan Nomor 242 /PMK.03/2014 tentang Tata Cara Pembayaran dan Penyetoran Pajak. Jakarta.

Kementrian Keuangan. (2014). Peraturan Menteri Keuangan Nomor 243/PMK.03/2014 tentang Surat Pemberitahuan (SPT). Jakarta.

Laihad. (2013). Pengaruh Perilaku Wajib Pajak terhadap Penggunaan E-Filing Wajib Pajak di Kota Manado. Universitas Sam Ratulangi Manado. Manado

Pandiangan, L. (2008). Modernisasi \& Reformasi Pelayanan Perpajakan Berdasarkan UU Terbaru. Elex Media Komputindo. Jakarta

Peter, S., Delone, W. H., \& McLean, E.R. (2008). Measuring Information System Success : Models Dimensions, Measures and Interrelationships. European Jurnal of Information System.

Rakayana, W. (2016). Persepsi Kebermanfaatan, Kemudahan, Kepuasan Wajib Pajak Orang Pribadi pada Penerapan Sistem EFiling terhadap Kepatuhan Pelaporan SPT Tahunan. Jurnal Ilmiah Mahasiswa FEB, 4(2). 
Republik Indonesia. Undang-undang Nomor 16 Tahun 2009 tentang Ketentuan Umum dan Tata Cara Perpajakan (UU KUP).2009. Jakarta.

Surjati, (2007). Analisis Sistem Integrasi Jaringan WIFI dengan Jaringan GSM Indoor pada Lantai Basement Balai Sidang Jakarta Concention Center.

Solikah, M \& Dian., K. (2017). E-filing pada Kantor Pelayanan Pajak Pratama. EkoNiKa, 2(2): 127-141. 